\title{
PERSONAL DEIXIS AS ADDRESSING SYSTEM TO EXPRESS SOLIDARITY AT CAMPUS COMMUNITY
}

\author{
WinantuKurnianingtyas SriAgung \\ STAIN Ponorogo \\ winantu.kurnianingtyas@gmail.com
}

\begin{abstract}
.
This research investigates personal deixis that indicate solidarity in campus environment. Students and lecturers conversation transcription were collected and analyzed by the researcher to identify the types of personal pronoun that commonly used to pointer the participants. The result showed that there were three kinds of pronoun used commonly by the participants and those indicate close relationship among others such as first person singular, second person singular, and third person plural. The finding revealed that the second person singular of bro, sist, and jeng are common in pointing speakers' audience. Eventhough, those become slang language in society. The implication of this research suggested for other types of pronoun to be exist in campus environment and indicate power.
\end{abstract}

Key words

Personaldeixis, addressing system, and solidarity

\section{INTRODUCTION}

Language is very essential in human life as an instrument to communicate, express the idea, share knowledge and information. In communicating, the speakers have to master the setting, the topic, the event, the way to communicate and so on. Communication practice may be, however, it constitutes a message-which requires a shared code, communicators who know and use the code, a channel, a setting, a message form, a topic, and event created by transmission of the message(Littlejohn, 2008).

Those mean that a speaker ought to capable of distinguishing with whom he speaks to, what the topic talks about, when he speaks, what code 
he uses, etc when communicate with others, because those terms will influence the message of communication. If we talk about language, we cannot take it up from the society. There is a close relationship between language and society because both are two things that influence each others. Wherever the society, there must be a language used for communication.

Although language is used by society, language has the particular roles relevant to the situation and event when the communication holds. Hence, someone may not use his own manner to express about something by himself in speaking. An individual's speech patterns are in part dependent on the person to whom he is talking, the topic of the discourse and the setting in which it takes place (Coupland, 1997).

Those means that before taking a part into a communication, the speaker must understand in what context they speak whether he speaks in formal or informal context. Moreover, the role-relationship between the speaker and hearer, for instance, the communication between parents to children, a boss and his employee. Then, the setting of the communication, for instances, at home, office, market, etc also becomes the major factors in conducting communication.

Language allows community not only to communicate with others but also to establish personal identity among individuals and communities in economic, social, and politic contacts. Language is not simply a means of communicating about weather or any subject. It is also a very important means of establishing and maintaining relationship with other people(Trudgill, 1974).

When a speaker tries to establish his personal identity in communicating with someone else, there will appear that the social cultural background affects the language, which he uses to speak. A socio-cultural 
construct abstracted from topics of communication, relationship between communicators, and locales of communication, in accord with the institutions of a society and spheres of activity of a speech community.

It means that language, which is affected by social cultural background, is usually used to identify the social class and status of the speakers. When language is used by society, the characteristics of the language are determined the groups accorded to differential status and prestige. Social class may be defined primarily by wealth, or circumstances of birth, occupation, and other criteria specific to the group under circumstance. Status is often largely determined by social class membership, but age or education may be more salient, or whether a person is married and has children or not.

The social class or social stratification exists in the term of power and solidarity. The existence of power and solidarity reflects in the way people communicate with others and it can be seen through the language they use. The same speaker uses different forms when talking to someone in a superior versus someone in an inferior social position, even within the same conversation. On the other hand a speaker has to mark the different terms of language when he speaks either formal or informal events and he also distinguishes to which he speaks such superior, inferior, familiarity, close friends, relatives, etc.

In communication event with other people such as greetings, introductions, expressing gratitude, the order of addresses may mark relative difference of closeness. For example, someone and his addressee in equal status and solidarity use a short form of his first name. Contrary to someone who was less equal status and super ordinate uses his title and last name.

That condition generally rises in daily interactions. As does in an 
institution, which social stratification seems to exist more. One who has higher position tends to have power to one who is in low position. However, he also shows the solidarity when he is speaking in informal situation once a while.

Personal deixis takes the main roles in justifying someone has power in his/her society or solidarity has priority one. In showing powersolidarity can be identified when the participants used personal deixis such kulo, bro, sist, sampeyan in addressing the other participants.

\section{LITERATURE REVIEW}

\subsection{Personal Deixis}

In pointing the participants whether the speaker and the hearer should understand the concept of pronoun. Personal deixis deals with the predetermination of the role of participants in the speech event in which the utterance in question is uttered and it is reflected directly in the grammatical categories of person(Trudgill, 1974).Verhaar (1993) indicated that personal deixis that can be considered as 'trully' deictic are personal pronoun, first and second person pronoun.

In ordinary, Cruse (2004) stated that other than first person, known as speaker and second person, known as addressee, another important participant in the speech situation, neither speaker nor hearer are also included to person deixis, that are known as third person.However, as stated by Burling and Ingram in Levinson (1983), pronominal systems also can be considered deictic. Those pronominal systems are as follows: for first person, speaker inclusion $(+\mathrm{S})$; for second person, addressee inclusion (+ A); and for third person, speaker and addressee exclusion $(-S,-A)$. Besides, in many languages, there are two first person pronouns plural known as 
exclusive and inclusive 'we'. As the term, exclusive 'we' includes speaker and other, but excludes the addressee $(+\mathrm{S},-\mathrm{A})$, whereas inclusive 'we' includes speaker, other and addressee or / +S, +A/ (Levinson, 1983). Let's take a look at the examples below:

2) Let's go to the cinema

3) Let's go to see you tomorrow

The sentence (2) is inclusive as it includes the addressee, while the next one (3) is exclusive as it excludes the addressee. In the fact that -'s in the word "let's" stands for 'us', it may be inappropriate for the second sentence because the word 'us' is considered inclusive while the second sentence is exclusive as it also mentions the pronoun 'you' (Levinson, 1983).

\subsection{Linguistics Signals of Power and Solidarity}

Special characteristics that indicate power and solidarity can be seen from the diction, and individual relationship. Individual relationship here shows that each individual needs to understand how he / she see the relation.

Hudson (1980) explains three linguistic signals of power and solidarity, namely:

\section{Addressed System}

This system is used to address someone in certain context and it depends on the relationship between the addressee and the speaker. The terms of address can be pronoun, position, and so on. It includes the speaker (the first person), the addressee (the second person) and the one (s) mentioned in the conversation (the third person). 
Term of address may show the signal of power and solidarity. By using the chosen term of address choice, someone can guess whether the addresser expresses his honor to the addressee meaning that he shows the power or expresses solidarity by using familiar term of address. For instance, in Javanese language, there are some terms of address such "kowe, sampeyan, panjenengan" for addressing "you" in English and "kamu" in Indonesia. In Indonesia especially in formal situation if someone says "kamu" he commonly shows power but when says "andd" usually meaning solidarity.

\section{Verb-Forms}

Hudson (1980) implies some language, which show direct relation between power and solidarity and verb-forms are used. They are Javanese and Korean. There are some suffixes which show distinctive power and solidarity relation between the addressor and the addressee, and a verb must obtain one of these suffixes attributed it. For examples in Javanese language performs the words "mbadok, mangan, nedha, and dhahar" for "eating."

\section{Vocabulary Level}

The last type is vocabulary level. According to Geertz in Hudson (1980), Javanese is good example which proposes a variety of alternative forms, listed in Lexicon, for each of a large number of meanings. Javanese has three forms for house, namely "omah, griya, dalem" which connote higher relative status of listener with respect to the speaker. 


\subsection{Related Studies}

The previous study is taken from NitaBonita Samosir thesis entitled An Analysis of Deixis in the Article of The Jakarta Post. This research concluded that there were five types of deixis which were used in article of The Jakarta Post namely person deixis, place deixis, time deixis, discourse deixis and social deixis. The most dominantly types of deictic word which is used in article of Jakarta Post is 99 occurrences person deixis $(42,85 \%)$. The dominant deictic word pointing to the person is "He" followed by "His" (Samosir, 2012).

Moreover, the researcher also takes a journal entitled Code switching as a Power and Solidarity Strategy in the Foreign Language Classroom an Analysis of Language Alternation Strategies Utilized in a Portuguese-English Higher Education Class written by Victoria Walker (2010-2011). This paper has provided evidence of classroom CS and its socially motivated properties. Rather than a metaphor for a community, the researcher hopes to have been able to demonstrate how power and solidarity are established through interaction in foreign language classroom discourse, as illuminated by my ethnographic study of the community. Accordingly, the researcher has demonstrated how the 'brought along' and 'brought about' approaches to CS data are not binary, but can in fact complement and support each other.

The data that the researcher has collected is small and so precludes the ability to make universal statements based solely on these results. The researcher has, however, been able to provide a detailed analysis of one example of CS and its social role in the classroom. It would also be interesting to study the same class in the presence of another teacher with a different teaching style to analyze how CS strategies are employed. A subsequent comparison of the data, alongside students' opinions and exam 
results, could provide a greater insight into the utility of my findings in relation to teaching strategies. This paper can also be used alongside other studies to establish a greater understanding of classroom CS at the advanced stage of foreign language education.

\section{Methodology}

The respondents involved in this research were English Department students and lecturers in STAIN Ponorogo. The researcher used purposive sampling because all of the respondents were taken from English Department Students of third semester and also English lecturers and they were purposively chosen by the researcher since they are considered as ESL used. All of them also shared similar characteristics; Second language used and Javanese people.

The research design was a qualitative type research design which concentrated on personal deixis. In this procedure, the researcher observed and made conversation transcription during the lesson and English lecturer forum. Hence by using this type of design, it generated deeper analysis from the respondents which later contributed more to findings. To find out the personal deixis that exists on conversation among campus community, transcript of conversation were required.

\section{RESULTS AND FINDINGS}

The conversation shown solidarity while the participants used different personal deixis to whom they speak up in the different context depend on social distance or social status of the participants. This could be mean that the speakers have higher position than the audience or the speakers have in lower position than the audience. Furthermore, the speakers 
could be equal position as the addresser but different in ages or they are in equal position and ages. Eventhough the participants are in different condition of social distance but they determine to use some distinguishes term of pronouns In this case, the participants of the conversations used saya and $\mathbf{a k u} / \mathbf{k u}$ to present solidarity condition.

\subsection{First Person Singular}

First person singular means grammatical category used in the classification of pronoun according to whether its pronouns indicate the speakers or the addressees in conversation. Its pronoun is referring solidarity expression in conversation while the participants or speakers or addressees are in equal positions. On the other hand, its expression could be occurred when the speakers are older than others or could be shown as closer relationship among the participants. The form of first person singular that shown that condition in this research is saya such in the following examples of conversation between the lecturer and students

L : Maafsayalupamembawaabsensi kalian.

Mintatolongsalabsatudiambilkan di mejasayaya

Ketuakelasnyasiapa?

Mintatolongya

ST : Iyabu, permisidulu

$L \quad$ : Terimakasibya

According to the conversation above, this could be seen that in fact, lecturer has unequal social distance with his students whether the position and ages. Then he should have a power to underestimate his students. However, by using pronoun saya, the lecturer tries to omit the gap between lecturer and students. As the result, lecturer wants to show that he has close relationship with his students. 
Another conversation that presents solidarity among campus community could be in the following. Its conversation hangs the lecturers as participants.

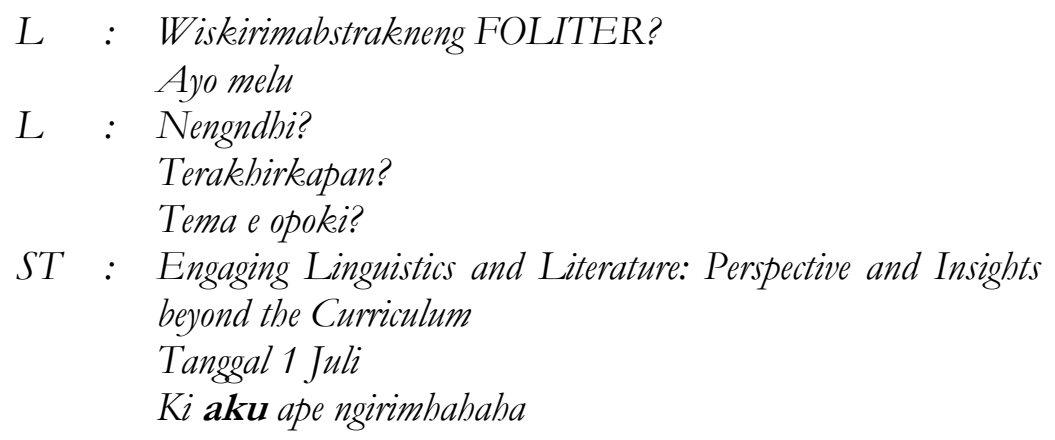

The participants of the conversation above are lecturers. In this case, the lecturers are in equal social distance and also the ages. In their discussion, they could be used informal language eventhough it happened at office. By choosing the first person singular akuin point out the other participant. This pronoun is used to show that both are solid each other.

Based on the explanation above, the researcher underlined that first person singular in term of subject pronoun akudansayaoccurred on the conversation among campus community and they represented solidarity among the participants.

\subsection{Second Person Singular}

Second person singular point of view is used to address the speaker's audience. On the other word, this could be said as addresser. The addressee will use different terms of subjective pronoun in pointing the addresser who has equal social status. This means that the addresser is as same position/level as the addressee/ speaker.

However, in other cases, its personal pronoun is used to pointing the addresser who has lower level in social class than the addressee. For that 
reason, the researcher analyzed the kinds of second personal pronoun in subjective case that occur on conversations among campus community which represent solidarity as the following examples

$$
\begin{aligned}
& L \quad: \text { Mpokisjuri story telling gakminggudepan? } \\
& L \quad: \text { Kapan? } \\
& L \quad: \text { Sabtudepan } \\
& L \quad: \text { Karopak A ma bu W } \\
& L \quad: \text { Okelah }
\end{aligned}
$$

That is the conversation between lecturers. To stand a solidarity condition between the participants, pronoun mpok is used in pointing speaker's audience. Mpokis Betawi mother tongue that represents a female person who is older or equal in ages. In this case, between the addressee and addresser are in equal social status and same in level of age. Moreover, the participants are Javanese people but they adopt Betawilanguge in showing their close relationship.

Then, another term of second person singular that also occurs on conversation among campus community is bro, such the following example

$$
\begin{aligned}
& \text { L : BropernahngajarBahasaInggris? } \\
& \text { IkingajarBahasaInggrisgak? } \\
& \text { Nyelang Course Outline e yo } \\
& L \text { : Tas semester ikingulangsakekelas PAI } \\
& \text { Peanyodapat a bro? } \\
& \text { Ayo garap CO barengbro ben penak } \\
& L \text { : Akumalahrongkelasbro PGRA ma PAI } \\
& \text { Yo op kategarapwongbuku e gakduwe } \\
& \text { Engkoaenyelang sing wis tau garapbro }
\end{aligned}
$$

In contrary to previous example, the participants of the conversation above are lecturers. Bro is chosen by the addressee in pointing the addresser. This word is adopted from English language brother that means a close 
friend who accompanies his buddies in their activities. On the other word, this could be said that between the participants have close relationship. So that in showing their relationship, the word bro considered to express their friend relationship.

Those kinds of expression also emerge in the following example of conversation:

$$
\begin{aligned}
L: & \text { Sistnyelangbuku English Intensive Course e yobesok ate } \\
& \text { ngulangdurungentukbukune } \\
L: & \text { ee...eee...iyo a sist? } \\
& \text { Gonkudurungtakgoleki } \\
& \text { Tapijaresudabbisadiambil di gedung D sist } \\
L \quad: \quad & \text { Oiyoa yowisengkomaringajartakambil e. } \\
& \text { Sumunyosist... }
\end{aligned}
$$

In line with the previous discussion, the participants of that conversation are also lecturers. They discuss about a teaching English book. At this time, the addressee prefers to use pronoun sist than other pronouns in reflecting their relationship. In this case, the lecturers have equal social class at this campus and also have the same level of age.

Automatically, they are more comfortable to make their relationship become closer. On the other hand, sistis the abbreviation of sister in English that means a term of address for attractive young women.

Through this research, the researcher defined the other term of second person singular that occurs on conversation among campus community, as follow:

$$
\begin{aligned}
L & : \text { Penelitiannewisdicetakjeng? } \\
L & : \text { Hahaha during marisikngumpulno data } \\
& \text { Terakhirkapan to? } \\
& \text { Emangwismari a jenggonmu? } \\
L & : \text { Durungkaetikonganalisagakmari-mari }
\end{aligned}
$$


According to the conversation above, the second person singular that used by the participants is jeng. Its pronoun is chosen because both have equal level/position as lecturer at this course. Afterwards, they are coeval of age. Moreover,jeng is taken from Javanese diajeng. Now days, its pronoun become a slang language and common to use in our society especially for women who has equal in ages.

That situation also defined at this community, mostly, jengis often used in pronouncing someone else who is in equal age by the youngest lecturers but it is used only in informal situation.

Then, dealing with solidarity expression, the researcher is looking forward another term of personal deixis and she turns pronoun masup to express solidarity as the following conversation:

$L \quad$ : According to the definitions that your friend write, we can said semantics is the study about meaning of words, phrases, clauses, and sentences in natural language or conceptual meaning. Sudabjelas? Ada yang ditanyakan?

\section{MasZainulsilabkan}

ST : Yang dimaksuddengan natural language ituapa?

L : SudabdibacabukunyaMas?

Natural language itumaknabisadilihatberdasarkankarakteristikdari kata yang dirujuk

The participants of the conversation above are student and lecturer in semantics class. Eventhough, the participants have different social distance at this course and also different level of age but they are intimate. This means that as lecturer, she absolutely is in higher position than her students. Then she is also older that ones. However, she did not want to treat her students. She decided to use masin pointing her students and made the situation and condition more intimate. 
Furthermore, pronoun mbakis also used to express solidarity among the participants as conversation below

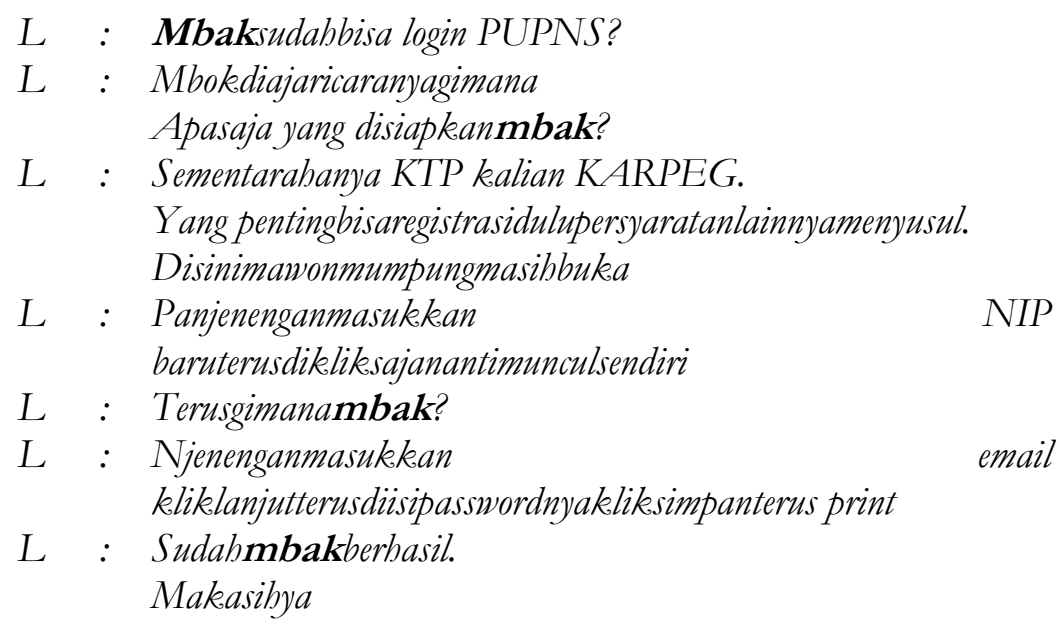

According to the conversation above, this is drawn clearly that mbakis used to point the speaker's audience out. The participants of the conversation above are lecturer but they are in different level of age. One lecturer is older than other. However, they want to build their relationship closer. So that, the oldest prefers to use pronoun mbakin addressing than others addressing system.

Pronounsaudaraas second person singular also presents solidarity expression such the following conversation between the lecturer and student at class

$L \quad$ : Kenapawaktunyapresentasitidakada bisamenjelaskanmaksuddariapa yang sudabdipresentasikan? yang Apasaudarabelummembaca?

$S$ : Maafbumemangbelumsemua kami siapkan $T$

L : Lain kali sayatidakmankejadiannyasama. Saudaratolongbanyakmembacasebinggabisamempresentasikanmak alabdenganbaik. 
That conversation occurs at class and the situation is in formal. However the lecturer tried to keep the gap away with his students. In this case, the lecturer wants to reprimand his students about their presentation. But he did not use his power in mentioning. In fact, he decided to use saudarain addressing his student and its pronoun shows that both are in intimate relationship.

The last second personal pronoun that the researcher defined and represented solidarity expression is pronoun sampeyan. In the following conversation, the speaker in pointing the addresser used sampeyan

$$
\begin{aligned}
& L \text { : Tolongsampeyanliatkan LBKD punyakudimejanya Pak } S \\
& \text { ya } \\
& \text { Lekwisditandatanganitolongsampeyan WA } \\
& \text { yoengkoitakambil e } \\
& L \text { : Iyo maringenetakincengenengruangdosen } \\
& \text { Lekwisditandatanganitakomongi } \\
& L \text { : Ok .... Siïp } \\
& \text { Ikisampeyansikngajarmaneh a? } \\
& L \text { : Iyo siksakekelas }
\end{aligned}
$$

The participants of the conversation above are lecturer. They are in equal position and ages. They discussed about teaching report and this conversation happened in rest time of teaching and learning process. Both used the same pronoun in pointing each other. This indicated that they have close relationship.

According to the examples and the explanations, the researcher concludes that second person singular occur on the conversations among the participants are mpok, bro, sist, jeng, mas, mbak, saudara, and sampeyan. They represent solidarity expression. 


\subsection{Second Person Plural}

Second person plural has similar meaning as second person singular. The different would be the mount of the participants. Its pronoun said plural because the participants are more than one. Meanwhile, second person means the way the speakers addressing theirs' audience.

In this session, the researcher defined second person plural that indicated solidarity expression on the conversation among campus community. Its pronoun is kalianand this pronoun clearly defined in the following conversation between lecturer and students

L : Untukpenyusunanlaporanskripsitolongkaliansalingkomunikasiunt ukemempermudabdanmempercepatpengerjaan

Kaliansatutimjadiharussalingmembantujanganjalansendirisendiriya

$S$ : Yapakterusuntukkonsultasihariapapak

$T$

$L \quad$ : Setiapsenindanjumat jam 08.00-12.00

Sebelumkonsultasitolong kalian siapkanbahan yang mauditanyakanapasaja

To obtain the intimate situation during thesis consultation between the lecturer and students, the lecturer used second person plural kalian in pointing his students. On the conversation above, it is clearly describe that the lecturer gave explanation about thesis consultation procedures.

Dealing with the lecturer explanation on that conversation, the lecturer could have power to his students in doing their thesis but in fact, the lecturer prefers to use kalianin building close relationship with his students.

According to the explanations and examples of personal deixis which indicates solidarity expression, the researcher concludes that its pronouns that occur on conversations among campus community are first, in terms of first person singular (sayaand aku); second in term of second 
person singular (mpok, bro, sist, jeng, mas, mbak, sampeyan, and saudara); and the third is in term of second person plural (kalian).

\section{Conclusion}

The personal deixis that exist on conversations and indicate solidarity is in term of first person singular (saya and $\mathbf{a k u}$ ); second person singular (mpok,bro, sist, jeng, saudara, sampeyan); third person plural (kalian). Now days, the second person singular of bro, sist, and jengare common in pointing speakers' audience. Its pronoun becomes slang language in society.

\section{Acknowledgements}

The writer would like to thank Tadris English Students and all English lecturers for helpful involving research.

\section{REFERENCE}

Berg, B. L. (2001).Qualitative Research Methods for the Social Sciences. California: Allyin Bacon.

Biklen\&Bogdan. (2007). Qualitative Research for Education: An Introduction to Theories and Methods. USA: Pearson International.

Coupland, N., \& Adam J. (1997). Sociolinguistics A Reader and Coursebook. United States of America: St. Martin's Press.

Cruse, D. A. (2004). Meaning in Language: An Introduction to Semantics and Pragmatics. Oxford: Oxford University Press.

Given, L. M. (2008).The SAGE Encyclopedia of Qualitative Research Methods. California: SAGE Publications, Inc,.

Gumperz, J. (1977). The Speech Community in Pier GiglioedLanguage and Social Context. New York: Penguin Books.

Holmes, J. (1992).An Introduction to Sociolinguistics. New York: Addison Wesley Longman.

Hudson, R. A.(1980).Sociolinguistics.Cambridge: Cambridge University Press. 
Hymes, D. (1972). On Communicative Competence in J.B Pride and J. Holmes (Eds.), Sociolinguistics. Harmondsworth: Penguin.

Labov, W. (1972). Sociolinguistic Patterns. Philadelphia: University of Pennsylvania Press.

Levinson, S. C. (1983).Pragmatics. Cambridge: Cambridge University Press.

Littlejohn, Stephen. (2008). Theories of Human Communication. California: Wadsworth Publishing.

Maulana, R., \&Opdenakker,M. C. (2014). Do Teacher-Student Relationships Deteriorate Over Time? inBarry J Fraser and Jeffrey P. Dorman Interpersonal Relationship in Education: From Theory to Practice. Roterdam: Sense Publisher.

McMahon, A. M. S. (1994). Understanding Language Change. Cambridge: Cambridge University Press.

Norman, F. (1984). Language and Power. United Kingdom: Longman.

O'Grady, W. D., Dobrovolsky,M., \&Katamba,F. (1997). Contemporary Linguistics: An Introduction. London: Longman.

Purwo, B. K. (1984).DeiksisdalamBahasa Indonesia. Jakarta: BalaiPustaka.

Robert, \& Cooper. (2012).Qualitative Research in the Post-Modern Era. New York: Springers.

Samosir, N.B. (2012). An Analysis of Deixis in the Article of The Jakarta Post. (Undergraduate thesis, State University of Medan, 2012). Retrieved from http://digilib.unimed.ac.id/16792/

Seidmen, I. (2006). Interviewing as Qualitative Research. New York: Teachers College Press.

Stake, R. E. (2010). Qualitative Research: Studying How Things Work. New York: The Guilford Press.

Sutopo, H. B. (2006).MetodePenelitianKualitatif. Surakarta: UNS Press. 
Trudgill, P. (1974).Sociolinguistics: An Introduction. Great Britain: Hazell Watson and Virey Ltd.

Verhaar, J. W. M. (1993). PengantarLinguistik. Yogyakarta: GajahMada University Press.

Walker, V. (2010-2011). Codeswitching as a power and solidarity strategy in the foreign language classroom an analysis of language alternation strategies utilised in a Portuguese-English higher education class. Innervate Leading Undergraduate Work in English Studies, 3, 358. Retrieved from

https://www.nottingham.ac.uk/english/documents/innervate/1011 $\angle 1011$ walkersociolinguistics.pdf

Yule, G. (1996).Pragmatics. Oxford: Oxford University Press. 